\title{
Exhuming and highlighting the nearly forgotten Gold Coast intelligentsia: The life and times of Prince Kwamin Atta Amonoo V
}

\author{
James Gibbs \\ Independent scholar, Retired Academic \\ Email: jamesgibbs@btinternet.com
}

Submitted: January 28, 2021 / Accepted: March 29, 2021/ Published: August 27, 2021

\begin{abstract}
The name K. A. Amonoo sits in the Roll of Honour in the entrance hall of Queen's College, Taunton, Somerset, England together with the names of other former pupils who served in the First World War. In recent times, focus on K. A. Amonoo has been on his palatial residence, which he built in Anomabo, a coastal town in Ghana, in colonial Gold Coast, as Micots (2015 and 2017) have sought to emphasize in terms of the architectural design of his residence. Therefore, what this paper seeks to do is to bring to light a historically significant narrative of who Amonoo was, as a case study to examine and foreground the contributions of some of the nearly forgotten African intelligentsia of coastal Ghana. Through close analysis, the paper also places a central gaze on his activism within colonial Gold Coast and Calabar in colonial Nigeria as subtle moves to counter the growing authority of the British administration. Utilizing a set of key biographical prompts, the paper reflects on thematic issues such as class and status, modernity, and resistance to British colonial hegemony.
\end{abstract}

Keywords: Gold Coast Intelligentsia, Queen's College Taunton, National Congress of British West Africa, Calabar Improvement

League, Gold Coast Colony, World War I

\section{Introduction}

The name 'K. A. Amonoo' appears on the Roll of Honour in the entrance hall of Queen's College, Taunton, together with the names of other former pupils who served in the First World War. In the paragraphs that follow, I want to show why 
Amonoo's name is on the board, and draw together what I can about his life, death and legacy.

\section{Who was K.A. Amonoo and what did he do in the War?}

'Kwamin Atta Amonoo', also known as 'K. At(t) a-Amonu', 'Prince Amonu' and 'Lawyer Amonu', was the son of Amonoo V, the Omanhene or Omanhen of Anamabu. His name is on the Roll of Honour because he attended Queen's College, Taunton, (entering in 1906) and served as a corporal in the Gold Coast regiment during the War. He also helped to recruit soldiers. I will follow the spelling of the name in the immediate source.

\section{What do we know of his father, Amonoo V?}

Amonoo V was born 'Kwamin Tufuantsi' and had some years of formal 'Western' education, probably at a Methodist Primary School. He reigned in Anamabu, West of Cape Coast in the Gold Coast, from 9 April 1901 to 20 (or 21) March 1921. In The History of Anamabu: The Formation of the Town of Anamabu', he is described as

an able and wise ruler ... His administration was all that should be desired. He was a man of great intellectual force. He was bold and ever ready for criticisms. He was a deep thinker. His suggestions were wholesome. (p. 11. ${ }^{1}$ )

Amonoo $\mathrm{V}$ was a member of the Aborigines Rights Protection Society (ARPS) formed $1897^{2}$, and, from September 1916, a member of the Gold Coast Legislative Council (LEGCO). (Kimble, pp. 358-403.) Amonoo $\mathrm{V}$ is credited with improving the road between Anamabu and Cape Coast, he constructed modern public toilets and (fined) those who continued to use the

\footnotetext{
${ }^{1}$ For this and a number of other sources, I am indebted to Courtnay Micots whose thesis refers to Amonu and the house he had built in Anamabu in considerable detail. See also Micots' published articles and the references she has found in Cape Coast newspapers.

2 See “The Gold," 15-22 October, 1914, 6 April, 1916, 5..
} 
beach as a latrine. (Micots, p. 138.) He sent his Saturday-born son who was a twin, Kwamin Atta, to England for his secondary schooling.

\section{Where is 'Anamabu'?}

Anamabu lies some fifteen miles to the east of Cape Coast. It has been suggested that its name, for which there are various spellings, may be derived from a reference to the rock on which gulls settle just off the coast. ('Obonoma' - 'Rock of Birds".) $)^{3}$ Fashions in spelling have shifted and various forms are encountered: 'Anomabu' is increasingly used.

Accounts of the town's history are preserved in oral traditions, and in written accounts that have been published both locally and internationally. Very briefly, it seems to have been a Fante settlement that was advantageously positioned and became a focus for European rivalry from the Seventeenth Century. At various times, a Dutch Lodge and a British strongpoint, Fort William, were built in the town. Fort William included six dungeons in which captives were held prior to sale. ${ }^{4}$ For an extended period, the town had the dubious distinction of being the major point for the export of human beings from the Gold Coast.

${ }^{3}$ See Philip Briggs, The Brandt Guide to Ghana. Variants of the spelling, affected in part by first language orthography, include Anamabo, Annemaboe, Annamaboe, Annemabo, and, see text, Anomabo.

4 See https://howlingpixel.com/i-en/Fort_William,_Ghana The post card dated 1890; a plaque in the Castle indicates that the Fort is 'Gold Coast King George VI Memorial Youth Centre'. 


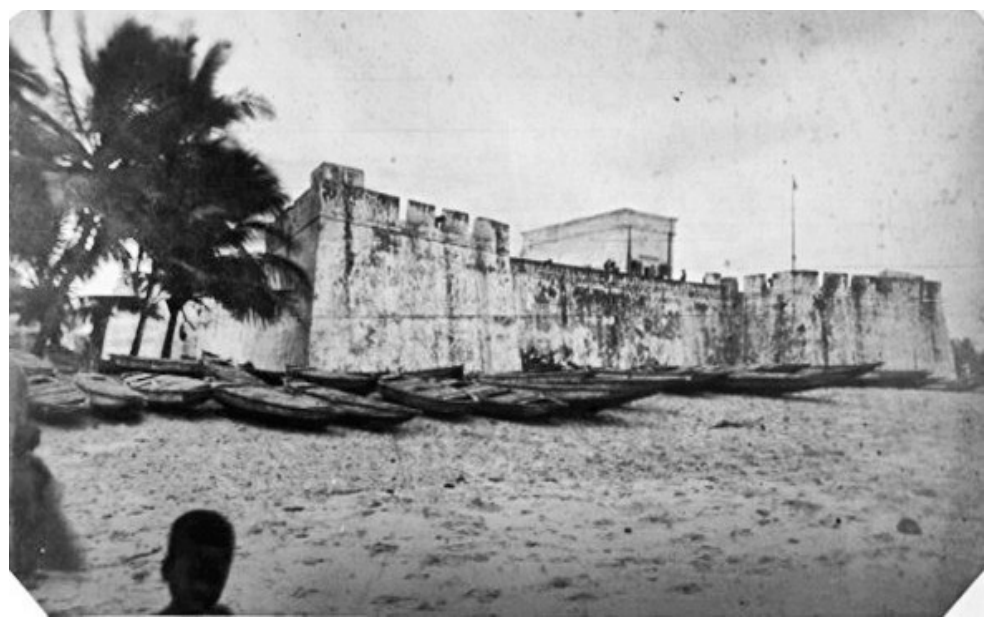

Physical sources for the history of the town include the Castle, various family houses, and the 'posubans' erected by asafo groups. ${ }^{5}$ Famous or infamous residents of the town include the Irish slave-trader Richard Brew (1725-1776), whose life has been written up, and his descendants.

\section{Famous sons on Anamabu}

Sons of the town who became well-known include Eno Baissie Kurantsi, 6 also known as 'John Coromantee', an astute trader and 'caboceer' 7 . That is to say, he was a merchant and a 'Civil Father' with a significant force at his command. In 1744, Kurantsi entrusted his son, William Ansah Sessarakoo (fl. 17361750) and a companion to the care of a British trading partner.

\footnotetext{
5 'Asafo' groups are strong presences in the town and their flag-waving displays are famous.

${ }^{6}$ Rendered in some sources that fuse name and title as 'John Bannishee Corrantee Ohinnee'. See http://docsouth.unc.edu/neh/royal/summary.html

${ }^{7}$ Kurantsi's mother is described on reproductions of the portrait as 'Eukobah Daughter of Ansah Sessarakoo King of Aquamboo \& Niece to Quishadoo King of Akroan'. 'Ansah' is sometimes rendered 'Unsah'. 'Aquamboo' is often referred to as Akwamu - a powerful presence towards the Volta. Randy J. Sparks writes about Sessarakoo's lineage in some detail (2014): he was the off-spring of strategic marriage, and could not be 'lost' - or made a slave without his father losing face. For a remarkable collection of pictures, maps, etc., visit http:// hitchcock.itc.virginia.edu/Slavery/index.php
} 
The understanding was that the young men would be taken to England. However, the captain renegaded on the agreement selling the boys into slavery in Barbados.

Aware that he had been deceived, Kurantsi exerted pressure on representatives of the Royal African Company (RAC) to have his sons redeemed and restored to him. (1744)

Having been traced in

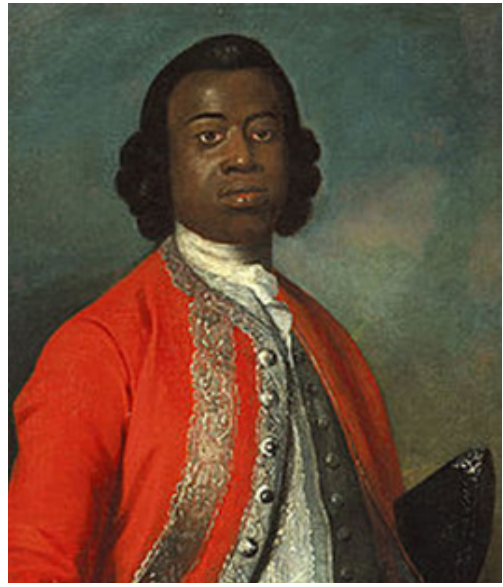
the Caribbean, the young men were taken to London where they were entertained and treated with courtesy. They were, for example, presented to George II, and attended a performance of Oroonoko. ${ }^{8}$ Sesserakoo's portrait was painted by Gabriel Mathias (see right) and parts of his story were worked up into The African Prince: Memoirs of the Young Prince of Annamaboe, a poem by William Dodd. (1749) ${ }^{9}$

Other sons of the town played major roles in opening up of the Northern Territories of the country, in politics, trade, and education. These include George Ekem Ferguson ('Ekem Atta', b. 1864), Nana Amonu Kantamanto IV (the Omanhene of Anamabu, 1868-1873), George Kuntu Blankson (1809-1898), John Mensah Sarbah (1864-1910), and Kwegir Aggrey, (a.k.a 'Aggrey of Africa', 1885/7-1927). These were remarkable men and it is an indication of the pride Anamabu takes in them that busts have been erected in 'Heroes' Park'. ${ }^{10}$

\footnotetext{
${ }^{8}$ Sesserakoo's emotional response to the drama, in which there were parallels for his own tribulations, was noted by onlookers.

${ }^{9}$ The theatre visit was described in the Gentleman Magazine, 19(1749) and 21 (1751), and Catherine Gallagher's edition of Oroonoko (2000), includes coverage of it. Sessarakoo's emotional response to action of stage-that echoed his own experiences, was used to indicate the sensibilities of Africans .

${ }^{10}$ Studies in whole or part on the town and its inhabitants include Priestley (1969), Shumway (2011), and Randy J. Sparks (2014).
} 


\section{Amonoo at school}

Having decided to send his son to school in England, Amonoo $\mathrm{V}$ chose a Methodist institution. It is likely that this selection was made because Methodist missionaries had established schools on the Gold Coast, including one in Anamabu.

In selecting Queen's College, Taunton, originally the 'Wesleyan Collegiate Institution', Amonoo V was opting for an institution that already had links with West Africa having welcomed the sons of the coastal elite since at least the 1860s. Names in the School Register from the second half on the Nineteenth Century include several with Fante and Cape Coast links. I suspect Amonoo V would have known, or known of, men with names such as Minneau, Sey, Hagan, Grant and Sarbah, who had attended the school. Of these, the most eminent was John Mensah Sarbah, lawyer, nationalist and educationist, who had entered Queen's in 1880. ${ }^{11}$

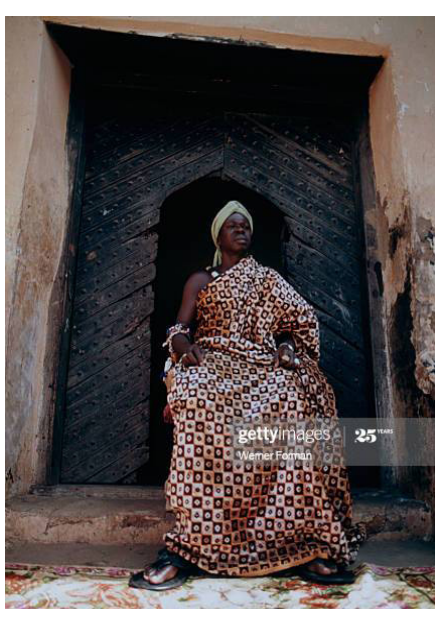

school into calmer waters.
Amonoo $\mathrm{V}$ was unlikely to have been aware of the year by year fortunes of the school and was probably ignorant of the fact that standards had dropped towards the end of the Nineteenth Century. However, Queen's was regarded as 'on the up' again from 1899 when A.S. Haslam was appointed headmaster: discipline improved and numbers increased. In the image employed by the school-historian, $\mathrm{H}$ J Channon, Haslam steered the [Picture from Anomabu.]

\footnotetext{
${ }^{11}$ Mensah Sarbah's brother died while he was a pupil at Queen's and Sarbah established a scholarship for Gold Coasters at the school. Information about the dead boy has proved elusive. For example, I do not know, for example, where he was buried.)
} 
In 1904, the pupil body numbered fewer than a hundred, but by 1906, when Amonoo registered, there were over 150 .

Amonoo entered his name in the School Register as ' $\mathrm{K}$. A. Amonoo'. This may be significant in that, at a time when West Africans in similar position might have opted to use Anglicized, 'school' or 'Christian names', Amonoo retained his surname and the initials of his 'home' or 'African names'.

He recorded his home address as 'Ahinfie, Anamabu'. In writing thus he made no concession to street name or box number, and he did not, as some did, enter the name of a British guardian. Ahinfie can be translated as 'Palace' or 'Royal House', and its location would be known to everyone in Anamabu. Amonoo felt no need to offer a translation.

He was given the pupil number ' 3620 '.

Beside his name in the Register we can read 'LL. $\mathrm{B}^{12}$. This is strange. And may either have indicated the legal qualification, Amonoo had already set his eyes on or have been added by a different hand at a later date.

We are fortunate to have a glimpse of Amonoo about the time of his registration from the hand of the man I have already described as the 'school historian'.

\section{'Dapper' Channon's recollection of Amonoo at Queen's}

Boy and man, in work and in retirement, the life of H. J. ('Dapper') Channon was inextricably linked with life at Queen's College, Taunton. ${ }^{13} \mathrm{He}$ entered the school as a pupil during Arthur Haslam's first years as Headmaster, reached the top of the school, took the University of London Matriculation examinations (January 1905) and then joined the teaching staff (1906). He then rose to become Assistant Master, or Deputy Head. When I met him in 1955, he was in retirement and nearing

\footnotetext{
${ }^{12}$ LL. B. = Bachelor of Laws (Legum Baccalaureus).

${ }^{13}$ In the absence of 'dates' I will hazard that 'Dapper' was born about 1885 and died in the 1960s. Precise information still being sought. Meanwhile, on his life, see https://www.bigredbook.info/dapper_channon.html
} 
the end of his work on The History of Queen's College, Taunton, that was published in 1956.

Perhaps surprisingly, Amonoo is not mentioned in the History. However, Channon had memories of him and, in 1950, referred to him - and the impact he made soon after his arrival- in an article for The Taunton Courier and Western Advertiser. There Channon wrote as follows: 'In 1906, Kwamin Ata Amonoo, a tall, fine-built, West African prince arrived (at the school), and, on the first morning of term, came down to breakfast in all the ceremonial outfit of a native chief.' ${ }^{14}$

Amonoo's dramatic appearance (the 'coming down' suggests he was descending the impressive staircase in the schools' entrance hall) reinforces the self-confidence hinted at by the information he inscribed in the Register. The decision to put on his 'ceremonial outfit' prompts reflection for, while 'native' dress was appropriate in the 'ahinfie', the decision of a student to wear chiefly robes in school was unexpected. In photographs of the period, and later, educated Africans generally presented themselves to 'the European gaze' in European attire.

One possible explanation for Amonoo's decision to wear 'cloth' is that he was defiantly 'himself'. As the son of a powerful man, the Omanhene, and as an inhabitant of the ahinfie in a trading town that had been dealing with European merchants, sea captains and soldiers for hundreds of years, Amonoo was brimming with confidence. In his choice of attire, he may also have been reflecting awareness of recent developments in Cape Coast; he might, for example, have heard that the eminent Old Queenian, lawyer and co-founder of Mfantsipim, John Mensah Sarbah, had worn 'native costume' to public events. ${ }^{15}$ Attitudes were changing and were affecting what was being worn.

14 'My 43 years as a school-master,' Taunton Courier, and Western Advertiser - Saturday,

11 March 1950. The fact that Amonoo is not mentioned at all in the History is particularly surprising since Channon devotes considerable space to the participation of Old Queenians who were involved in World War I.

15 See Appendix 1 for account of Mensah Sarbah wearing cloth to a 'concert'. 
Channon's use of the word 'prince' and his acknowledgement that his dress indicated Amonoo's status as a 'chief' shows that Channon the history teacher and historian was searching for English words that would convey his sense of who Amonoo was. Channon might not have been familiar with the term 'Omanhene', but he was feeling his way with respect - and in English already loaded with baggage when it came to describing Africans - to indicate social ranking in Anamabu.

The additional names Channon provides ('Kwamin Ata') provide information about Amonoo's birth and help in our attempts to follow his career. The day-name 'Kwamin', like the more familiar 'Kwame', indicates that Amonoo was born on a Saturday, and 'Ata' means he was a twin. In the renditions of the name that follow, the word is sometimes spelled 'Atta', a frequently encountered variant. It is worth noting Channon's reference to Ata-Amonoo as 'tall' and 'fine-built'. His age is uncertain, but it is possible he was in his mid-twenties.

After this vivid account of a moment near the start of Amonoo's time at Queen's, I am sorry to say I lose track of my subject. ${ }^{16}$ In the absence of indications to the contrary and in view of the outcome, I assume he followed the courses of study that the school offered - and that Channon himself had taken. This would mean that he prepared for examinations in five subjects in order to Matriculate. And pursue his education at tertiary level. In this case that meant embarking on legal training.

\section{"Lawyer Amonoo" / Lawyer Amonu}

In 1912, some eight years after his arrival at Queen's, Amonoo 'reappears'. In that year he satisfied the requirements for recognition by the Inns of Court and the name 'Kwamin AttaAmonu' was added to the Gold Coast Roll. ${ }^{17}$ Despite the slight

\footnotetext{
${ }^{16}$ I suspect there is additional information in the Archives at Queen's, school magazines and Taunton newspapers.

${ }^{17}$ Crabbe in Sarbah, 6. 
variation in spelling, this meant that 'our Amonoo' was entitled to practise as a lawyer in British West Africa. Henceforth he is often referred to as 'Lawyer Amonu'. ${ }^{18}$ I will sometimes use that variant on the spelling of his family name.

Having been through the Inns of Court and having been Called to the Bar, Amonu returned to the Gold Coast and took his place among the members of the West African coastal elite. He took up the place that was his by virtue of being his father's son, and as a Barrister. (He is referred to as 'Barrister AtaAmonu', in 'General', 8 February 2013, 2. )

Many members of that loose social group were members of the (Gold Coast) Aborigines' Rights Protection Society (ARPS). That Society had been set up in 1897, by making use of the judicial system the British had introduced, to challenge the Crown Lands Bill proposed by the colonisers. On occasions, however, the ARPS went above the Courts and appealed directly to Queen Victoria. In the years following the initiation of the campaign against the Crown Lands Bill, the ARPS continued to represent the interests of progressive holders of traditional offices, and of educated, professional men. The Society challenged the British and their evolving colonial ambitions. ${ }^{19}$

\section{The coastal elite and the Great War}

Within two years, of Amonoo's return to West Africa, the Great War broke out, and, like other discontented groups under the British crown, the ARPS was faced with a dilemma:

18 For the Roll, see the Ghana Judicial Website. http://archive.today/MWBmu). Micots writes 'It is unknown if he trained specifically as a barrister in England...' 148

${ }^{19}$ For a more nuanced account of the genesis and modus operandi of the ARPS, see Crabbe on Sarbah, 21. That account relates, for example, that Sarbah was paid 400 guineas to plead the case for the ARPS, but, having been paid, he returned the fee because he felt he was serving his people. It may be that this money was spent on printing equipment that contributed to the development of newspapers in Cape Coast. (See Jones-Quartey and Crabbe, 22.) Amonu IV of Anamabu had been associated with the petition about the alienation of land rights that was presented to Queen Victoria. By the second decade of the Twentieth Century, the ARPS was no longer in the forefront of agitation in West Africa and Amonoo played various roles in more radical, organisations. 
should the Society take advantage of the conflict to push forward its aims 'by any means possible', or should it cease agitating 'for the duration' in anticipation of being able to use the good will generated in the bargaining that would follow the War? Famously, some groups in the same sort of position, such as the Suffragettes, declared a 'truce', while others, such as the Irish Republican Army, took up weapons. ${ }^{20}$ To see which approach the ARPS opted for we only have to look at the British newspapers for 24 September 1915 where we can read that members of the Society collected $£ 1,500$ for the purchase of a plane for the Allies. It was inscribed 'Gold Coast Aborigines', and, with much ceremony and considerable news coverage, it was handed over to the British government. ${ }^{21}$

Ata-Amonu made a more personal commitment to the war effort and, on 24 November 1915, he enlisted in the Gold Coast Regiment. As the Medal Card held at the British National Archives, Kew and the Cape Coast press indicate, Ata-Amonu was given the identification number WO 372/1/140392, made a corporal, served in the Cameroons and was awarded a bronze star. ${ }^{22}{ }^{23}$ Inevitably many questions are raised by this some of which are answered by the reflection that the British army did not look beyond race when selecting officers, and the observation

${ }^{20}$ There was some variety of action: for example, the Women's Social Political Union (WSPU) declared an armistice while the Women's Freedom League (WFL) continued militant action.

21 'Aeroplane from Gold Coast', Edinburgh Evening News, 24 September 1915. The news item was carried on the same day in The Dundee Courier, Western Times and Evening Despatch. Micots lists “The Gold Coast Aborigines' War Fund', The Gold Coast Nation, 15-22 October 1914,2 . Amonoo is listed among ARPS member present at a meeting.

22 See also Gold Coast Leader, 26 August 1916, 5-6.

23 The rank and file was, for the most part illiterate, recruited from the Northern Territories (N.T.)or from neighbouring French territory. In 1914, 4I per cent of the G.C.R. came from within the N.T. and 59 per cent from outside, mainly from French territory. The latter figure had declined to a mere 5 per cent by I9I8: from an approximate calculation given in Roger G. Thomas 'Military recruitment in the Gold Coast during the First World War' (1975) , Cahiers d'Studes Africains, xv, no. 57 (I975). Report on the Combatant Manpower of the Native Races of British West Africa, 1923, gives figures for the totals of West Africans involved in the war effort. 
that the Gold Coast Regiment was led by white officers!

My next sighting of Amonu is again in connection with Ata Amonu's service to the British Army because - on 16 February 1917 - 'Atta Amonu', together with ARPS office holders and others, ${ }^{24}$ attended a recruiting rally in Cape Coast. He was among those who spoke to the assembled men. One hundred and fifty joined up at the end of the meeting. ${ }^{25}$

To place this appeal for recruits in context, it is helpful to recognise that the Gold Coast had been in the War from the beginning, and that, early in 1917 - after the losses on the Somme, the British army was seriously short of soldiers. ${ }^{26} \mathrm{By}$ saying the Gold Coast had been in the War 'from the beginning', I refer to a narrative that enshrines a Gold Coaster, from the Northern Territories, Alhaji Grunshi, as the first soldier fighting under the British flag to fire a shot in World War I. The skirmish Grunshi was involved in followed the despatch by the Governor of the Gold Coast, Hugh Charles Clifford, of men from the Gold Coast Regiment of the West African Frontier Force to seize a radio-station at Kamina Barracks, near Atakampé, in (German) Togoland. An exchange of fire took place at Nuatja near Lomé on $7^{\text {th }}$ August and these may have been the historic shots.

24 The party included the Hon. E J P Brown, Tufuhene Coker and T F E Jones, President of the ARPS. (See Kimble, 429, 453, also Thomas, 69, f/n 48.) For references to the support given to the British war effort see Killingray and his use of Methodist sources. He reports that, at a gathering held at Winneba, the Rev'd S. Attoh Ahuma offered 'fervent and incessant prayers for the unqualified success of British arms'. See Report from Gold Coast Methodist Synod Minutes, I915, quoted in H. W. Debrunner, A History of Christianity in Ghana (Accra, 1967), 277. Also see Gold Coast Leader, 3 March 1917.

25

26 Killingray, David, 'The Idea of a British Imperial African Army'. The Journal of African History, Vol. 20, No. 3, 1979, 421-36. (See in relation to ideas about 'A Million Black Army', 'like the French', and the Indian Army that the British had deployed in various Imperial contexts. The idea of a 'Black Army' found more support among those concerned with Defence than those in the Colonial Office. It is necessary to take notice of prejudices about Africans held by military leaders. See, for example, Sir Garnet Wolseley, 'The Negro as Soldier', Fortnightly Review, 44 (Dec. 1888), 689-703, Thomas (1975) quotes the text of a poster directed at able bodied men and playing on loyalties and pride. F/n 26. 
Gold Coast troops were involved throughout the War, fighting, for example, in Douala in the Cameroon / Kameroun, and then in the East African campaign. The latter continued after until November 25, 1918 and Grunshi himself served throughout; he had a very long war!

The Gold Coast Regiment had, traditionally, recruited most effectively from the Northern Territories, but wartime conditions - and losses - meant that recruiting drives had to be initiated in the South of the country. During the early months of 1917, new sources of manpower were identified and appealed to. With Amonu and his ARPS colleagues among the platform party appeals could be made to those with traditional loyalties as well with contemporary aspirations.
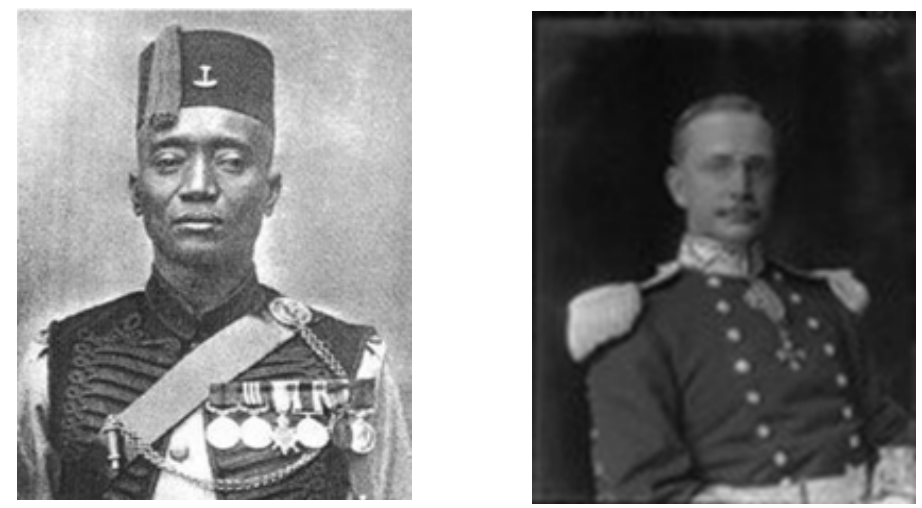

The composition of the platform party on 16/02/1917 reflected the pact between the Colonial Government ('The Castle') and the ARPS, that may have been brokered by (Alexander) Ransford Slater. Slater seems to have advocated the alliance while Governor Clifford was concerned about 'the price' that the ARPS might demand at the end of the war 'for services rendered'. ${ }^{27}$

27 Sir Alexander Ransford Slater portrait by Walter Stoneman, 1925, National Portrait Gallery. Slater's grandson, Sir Anthony Michael Goodenough, was High Commissioner in Ghana, 19891992. Killingray cites the exchanges that reflected the positions of Clifford and Slater regarding the use of African troops. Thomas, 1975, offers a meticulous analysis of relevant material regarding World War I. 
The roles Amonu played in the war must have been drawn to the attention of those at Queen's responsible for compiling the list of names to go on the Roll of Honour. The presence of his name there acts as a reminder of Amonu's role as a recruiter and as a member of the Gold Coast Regiment.

The Cape Coast newspapers of the period: glimpses of Amonu's life, for example, as an actor

On the $14^{\text {th }}$ and $21^{\text {st }}$ October 1916 , K.A. Amonu took the role of Lawyer Onymidzi in the production of Kobina Sekyi's The Blinkards staged in Cape Coast. The opening night turned into the opening two nights because the play moved so slowly the second half had to be staged a week after the first!

The problems with the staging were partly precipitated by the change of attitude of Methodists in Cape Coast. Plans were initially made for the performance of the play at Mfantsipim School, but permission for that to take place seems to have been withdrawn by those apprehensive of Sekyi's satirical intent. As a result, and at an advanced stage of preparations, the venue of the performance had to be changed to the Government School. Comments in the local press suggest that shifting the venue was a major undertaking involving, for example, the Public Works Department, the Roman Catholic hierarchy and pupils at Mfantsipim.

The première of Sekyi's major text was a major event in the history of European influenced performance in West Africa, and should be seen in context. In the years before the First World War, amateur dramatics had taken its place beside musical entertainments among the diversions of the Cape Coast middle class. That 'barrister' Ata-Amonu should take the role of the lawyer, Onyimidzi, in the play is striking and intriguing. He took the part of the character who is often allowed to speak on behalf of the playwright and must have brought the experience of being a lawyer - a 'brother' of Onyimidzi - to the interpretation of his role. 
Courtney Micots, who has researched Amonu's life and work, allows herself to speculate that Ata-Amonu and Sekyi might have been friends. They certainly must have worked together on the production and one can speculate that Amonu shared some of Onyimidzi's views and habits. It is tempting to see art imitating life and to seek opportunities to match the man with the character he played. The fact that some contemporary sources suggest that Sekyi attended Queen's College, Taunton, some years after Amonu, makes speculation about the relationship between the two men even more tempting.

\section{Other sightings: Ata Amonu and Cape Coast}

In 1917 Ata-Amonu was mentioned along with William Renner and Doctor Beckley 'as gentlemen (who) have embraced tee-totalism not because they could not control themselves but in order to set an example to their fellow young men.' ('News', 22 September 1917, 4. Reports are provided by a weekly newspaper, The Gold Coast Leader (GCL), that had been established in 1902 and that paid particular attention to the doings of the coastal elite.

In August 1919, Amonu attended a garden party 'in honour of William $\mathrm{C}$ Woodhouse Bannerman, the new police magistrate.' ('Garden Party', 16 August 1919 fn M 13.)

On 14 November 1919, the Central Province Committee of the British West African Conference, of which Amonu was joint secretary, met at Elmina, and there was a subsequent gathering in Accra, (3-10 January 1920) at which Nigeria, Sierra Leone and the Gambia were also represented present. ${ }^{28}$ Amonu was present with, for example, Van Hein and Brew. (British, 3-10 January 1920, 5. Also Editorial, 3-10 January 1920. The Lagos, 28 January, 1920, $7 \mathrm{~m}$ fn 14)

Perhaps during March (15-24 1920), Amonu seems to have been present at the first official meeting of the British West

\footnotetext{
${ }^{28}$ See Micots research, and her references to The Gold Coast Leader, 20-27 March 1920, 4; and Weekly News (Sierra Leone), 27 March. 1920, 8.
}

Legon Journal of the Humanities 32.1 (2021) Page 15 
African Conference that was held in Accra (Kimble, 1963). Meeting on 20-22 March, 1920, the 'Congress' replaced 'Conference' in the name of the organisation - which thereby became the National Congress of British West Africa. It is possible that the influence of India in the anti-colonial struggle may explain the change of name. (Kimble 1963, p. 383.)

Amonu introduced a discussion of the issue of Representation of 'West African views in London.' ('British', 9-17 April 1920; The Accra, 27 March 1920, 8-9 f/n M 17 SL papers.) There is a reference to a challenge to raise $£ 100,000$, but it seems that target may not have been reached. In the next two years the Conference stumbled on (Kimble 1963, p. 403.) ${ }^{29}$. During July, Amonu (with Sekyi and Brew) reported back to his fellow visionaries gathered in Saltpond. ${ }^{30}$

By 1919, Amonu had begun to show that he was becoming a man of substance: he was marshalling resources to such good effect that he had begun to finance the construction of a very substantial house in Anamabu.

It was also reported that Amonu was practising law in Nigeria, in an area of Nigeria that was prospering as a result of the export of palm-oil, Calabar ${ }^{31}$. It appears that a number of Gold Coasters had moved East to find work . ${ }^{32}$

Work went forward on Amonoo's house in Anamabu, and, on 31 August 1920, a 'house warming' was held to celebrate its completion. According to the Gold Coast Leader

\footnotetext{
${ }^{29}$ Gold Coast Leader, (9-) 17 Apr. 1920, 6-7; and Times of Nigeria, 12-19 Apr. 1920, 6-7

${ }^{30}$ Gold Coast Leader, 14 August 1920.

${ }^{31}$ At this point, I have drawn on Jones-Quartey's monograph on the Early Press in Ghana and on Azu Crabbe's study of Mensah Sarbah. These, however, do not always agree and both are limited by source material.

32 The 'expatriate' Gold Coast community remained exercised about politics 'at home'. This is shown by the fact that they sent a congratulatory telegram to Mensah Sarbah in 1910 after he had been conferred with a C.M.G. (Most Distinguished Order of Saint Michael and Saint George). Crabbe, 7.
} 
there was 'a large party in attendance'. ${ }^{33}$ The Band of the West African College of Music played and a most enjoyable time was spent (General 9 Sept 1920, 2 see Micots p 140)

Courtney Micots has written on the building and analysed the statement it makes through the play on architectural styles incorporated and by the nature of the spaces created inside the walls.

Amonoo family residence, west side, Kwamin Atta Amonoo 1920, stone nog, brick, concrete (paint added later), Anomabo, Ghana, 2009. Micot's photograph.)
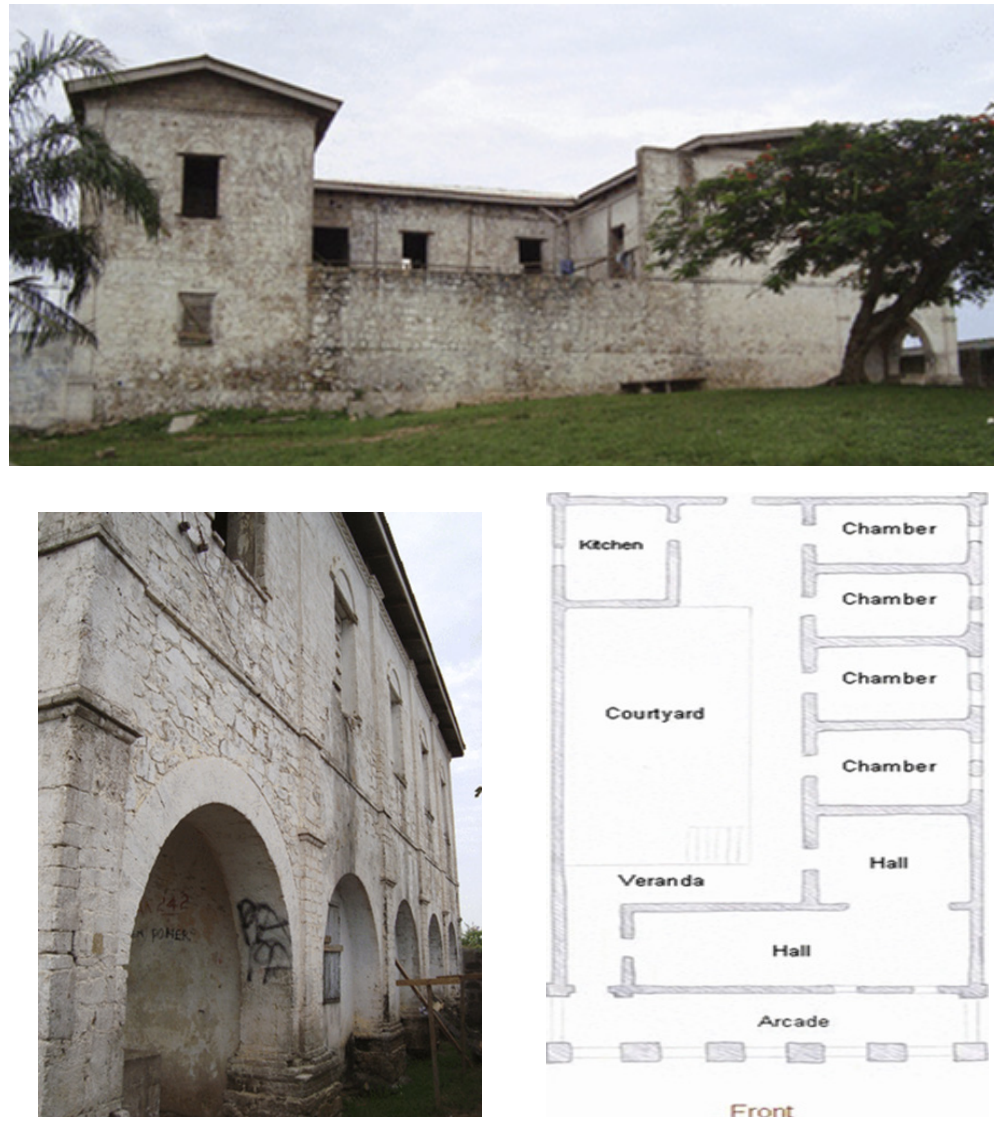

${ }^{33}$ GCL, 4/9/1920, 2. Micots, 238. Pictures at http://jsah.ucpress.edu/content/ucpjsah/74/1/41/ F21.large.jpg?width $=800$ \&height $=600 \&$ carouse $=1$

Legon Journal of the Humanities 32.1 (2021) Page $\mid 17$ 
Amonu travelled to the Gold Coast at the beginning of 1921 and on 29 January he was made Secretary of Central Province (Gold Coast) Committee of 'the National Congress of British West Africa' (NCBWA) ${ }^{34}$.

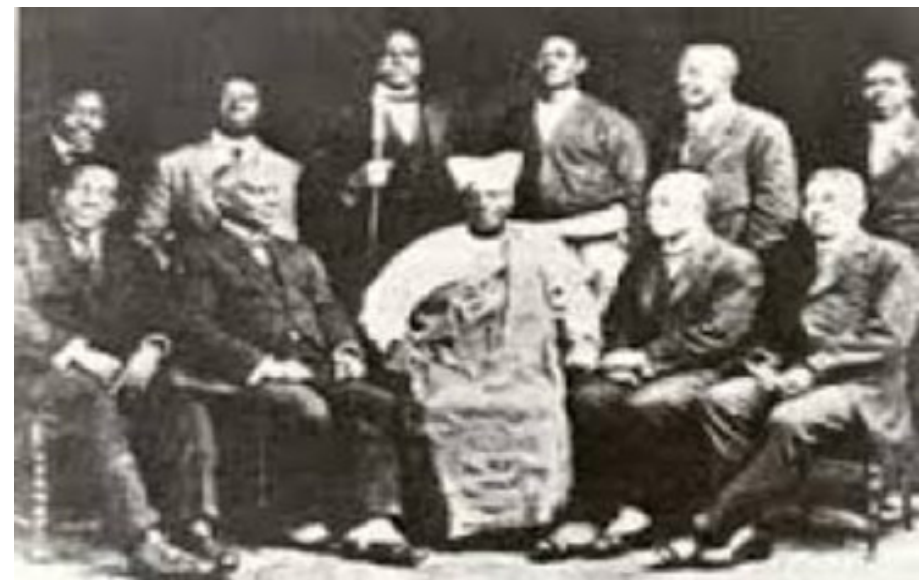

I think it likely that Amonu featured in photographs of the BCWA, such as that above. However, I have not succeeded in identifying him. Sources such as Michel R. Doortmont - The Pen-Pictures of Modern Africans And African Celebrities-A Collective Biography of Elite Society in the Gold Coast Colony may prove useful.

Amonoo travelled with Brew to Calabar. (See 'General,' 5 February 1921, Micots fn 21.)

In March, Amonu was being considered for the position of police magistrate at Winneba ('General' 12 March 921; 'Mixed Pickles' 17 December 1921.) (Police Magistrate posts were considered sensitive by the colonial forces, and local applicants were often rejected because they were suspected of invariably being biased.) $)^{35}$

\footnotetext{
${ }^{34}$ Micots has the organisation down as 'the Congress of Africans of British West Africa'.

${ }^{35}$ C. E. Woolhouse Bannerman applied to be a Police Magistrate or BNA in 1919. See Goldman on exchanges. CO 96/188, Confidential, 7.18.1887. 25 BNA CO 429/27, minute, 2.27.1908. 26 -179- District Commissioner in Accra.
} 
The NCBWA had been established at a meeting held in the Rodger Club, Accra the previous March, that had brought together fifty-two delegates from the four countries that made up 'British West Africa'. It represented a new stage in West African supra-nationalism and political activism, and made decisive statements about the international nature of the anti-colonial struggle. The Congress brought together a new generation of professional West Africans, doctors, lawyers, teachers, and journalists. It distanced itself from the stand taken by the ARPS by subsuming colonial boundaries in the notion of 'British West Africa'.

After becoming Secretary, Amonu returned to Calabar, but he was back in Anomabu within a matter of weeks, perhaps in response to a call from the family: he arrived home shortly after the death of his father to find rumours circulating that the death had been caused by witchcraft ${ }^{36}$. This was a reminder to the London-trained office-holder in an international anticolonial organisation of the different worlds he moved between. Accusations were made and, in due course, there was a hearing before a Native Tribunal. It seems that Amonu stayed in the Gold Coast performing filial duties for three months while this process took its course. ${ }^{37}$

\section{Amonoo and the Calabar Improvement League}

In 1922, Sir Hugh Clifford, who had succeeded Lord Lugard as Governor of Nigeria, prepared a written constitution for Nigeria ${ }^{38}$. This document, known as 'The Clifford Constitution', was controversial because, for example, it did not cover the North and because it ensured that the executive remained in the hands of the British. However, and possibly in response to pressure from the NCBWA, it did incorporate an elective element in that some of the seats in the Legislative

\footnotetext{
36 There is some uncertainty about whether Amonu V died on the $20^{\text {th }}$ or $21^{\text {st }}$ March 1921.

37 GCL 25/6/1921.

${ }^{38}$ Clifford's place in Accra had been taken by Gordon Guggisberg.
} 
Council (Legco) were to be filled as the result of a ballot. Though the franchise was narrow - only those who could show they had an annual income of $£ 100$ were eligible to vote - the principle of election was present and this was ground-breaking in the context of colonial rule in Nigeria.

Under this Constitution, 'Lawyer Amonu' / 'Prince Kwamina Ata-Amonoo' of Anomabo stood in Calabar for a seat on Legco, and won a four-way race by a single vote. In seeking an explanation for his success, that included pipping a well-connected 'son of the soil' to the post, ${ }^{39}$ it may be helpful to record the posthumous description of Amonoo given by an unnamed Nigerian source. The final words of the quotation speak volumes:

during his sojourn here I contracted an intimacy with him and found him to be a man who shunned snobbishness. He mingled with the proletariat, notwithstanding his professional or social status. Everybody has his or her own faults, but the deceased was very much liked if not for anything, at least, for his hospitality, affability and great sense of honour." 40

Ata-Amonu's success at the ballot box has ensured him 'a place in the electoral history of Nigeria'.

The article stated that -

Prince Kwamin Atta-Amonoo, Barrister-at-law, son of the late Honourable Nana Amonu V of Amanaboe, who is now residing at Calabar in Nigeria, arrived here this week with his friends Mr Lovelace Johnson, and Mr W. Ward Brew, Barrister-at-law who also lately returned from Europe. We gladly welcome Mr Brew and Prince Atta-Amonu in our midst.' CHK spelling of Amonu/oo Micots f/n 23. P 150

39 Emeka 'Ed' Keazor, http://nsibidiinstitute.org/notable-nigerians, see also https:// en.wikipedia.org/wiki/Nigerian_general_election,_1923. That source also has him down as an Independent.,

40 (“General News," Feb. 1, 1930, p. 6). Quoted in Micots. 


\section{Death on the road}

The next news I have of Amonu comes from seven years later, and is of disaster rather than triumph for at the end of 1929, Amonu was killed in a road accident when travelling from Accra toward Cape Coast, between Adaiso and Bawjiase. ${ }^{41}$

The introduction of petrol-powered vehicles and the extension of the road system were essential elements in the modernisation of communications along the coast. Those killed in motor accidents were often, as in Amonu's case, those pioneering new ways of life and new means of earning a living. A 'modern man', Amonu died a modern death.

It seems that modern accounts sometimes include the information that Amonu was making a final journey from Calabar to Amonabo, but there should be a caveat that such dramatic flourishes are often attached to lives, like Amonu's, that included long years of struggle and forfeited years of rest.

Prince Amonu's funeral was held at Anomabo on 28 January 1930. ('Rambling,' 27 December 1929, The Gold, 4-11 January, 1930)

\section{Coda}

There is, it seems, a myth current in Anamabu, where the house he built now stands neglected and in a poor state of repair, that Lawyer Amonoo never saw the house he had laboured in a foreign field to raise. ${ }^{42}$ On a literal level this is untrue - Amonu spent time in Anamabu following the housewarming party. However, on a deeper level, the myth may catch at a truth in that because his life was cut short he did not enjoy a leisured old age spent in the house he had spent so much effort to construct. Street maps of Calabar show that there is a road, 'Atamunu Street', that preserves in a locally comfortable form the name of the Gold Coast lawyer who played many roles in the course of his life. He was, for example, a student, lawyer,

41 1930, The Gold Coast Times. Micots includes information on this obtained from family members.

42 Micots reports this myth.

Legon Journal of the Humanities 32.1 (2021) Page $\mid 21$ 
soldier, recruiter, actor, Legco member, international activist, and house builder. His name lives on in Anomabo where the stool is occupied by Amonu X1. Along the coast, the people of Calabar, walk along a street named after him, and we know that at least one of his contemporaries recalled his virtues. The Prince was appreciated for 'his hospitality, affability and great sense of honour.' 


\section{References}

\section{Newspapers ${ }^{43}$}

The Gold Coast Leader 4.9. 1920, 2; 5.2. 1921, 2; 21.5. 1921, 7; 25.6.1921, 7; 25.8.1923, 2; 27.12.1923, 2;

The Gold Coast Times, January 4-11, 1930, 6.

Gold Coast People, November 30, 1893.

\section{Books and articles}

Anon. History of Anamabu: The Formation of the Town of Anamabu', n/d.

Ghana National Archives, Cape Coast. (Not seen, quoted Micots.)

Aroge, T. S. (2012). 'Civic Education as a Panacea to

Electoral Malpracticeds in Nigeria,_- Business and Management

Research, 1(1).daroge@yahoo.com http://www.sciedu.ca/journal/ index.php/bmr/article/viewFile/811/398

Channon, H.J. (1936). A Sportsman's Parables, London: Epworth. - (Saturday 11 March 1950). 'My 43 years as a school-master,' Taunton Courier, and Western Advertiser. (1956). History of Queen's College, Taunton, Published for the Old Queenians' Association, nd.

Crabbe, A. (1971). John Mensah Sarbah, 1864-1910, Accra: Ghana Universities Press.

Heap, S. (1989). 'The Development of Motor Transport in the Gold Coast, 1900-39.' Paper presented at the Royal Commonwealth Society, London. http://diaspora.northwestern.edu/mbin/WebObjects/ DiasporaX.woa/wa/displayArticle?atomid $=620$

Jones-Quartey, K. A. B. (1975). History, Politics and the Early Press in Ghana: The Fictions and Facts, Published by the Author, Legon. Killingray, D. (1978). 'Repercussions of World War I in the Gold Coast.' The Journal of African History, 19(1), pp. 39-59. https://www. sahistory.org.za/sites/default/files/d_killingray_repercussions_of_ world_war_i_in_the_gold_coast.pdf

${ }^{43}$ For Gold Coast newspapers see holdings at the Colindale repository of the British Museum and the Centre for Research Libraries digitized database. I have not accessed these newspaper sources first-hand. 
Gibbs, J./Exhuming and highlighting the nearly forgotten Gold Coast intelligentsia

Kimble, D. (1963). A Political History of Ghana, 1850-1957.

Oxford: Clarendon Press. On-line: https://archive.org/stream/ in.ernet.dli.2015.130230/2015.130230.A-Political-History-OfGhana_djvu.txt

Micots, C. (2010). African Coastal Elite Architecture Cultural Authentication during the Colonial Period in Anomabo, Ghana, $\mathrm{PhD}$ Thesis, University of Florida, Gainesville, Fla. See http://ufdc.ufl.edu/UFE0041366/00001/pdf

Micots, C. (2017). 'A Palace to Rival British Rule: The Amonoo Residence in Ghana, 'Critical Interventions: Journal of African Art History and Visual Culture, 11(2). Link: https://doi.org/10.1080/19301944. $\underline{2017.1363502}$

Micots, C. (March 2005). " "Status and Mimicry: African Colonial Period Architecture in Coastal Ghana", Journal of the Society of Architectural Historians, 74(1), 41-62. http:// www.famu.edu/fineartsprogram/Status $\% 20$ and $\% 20$ Mimicry, $\% 20$ JSAH $\% 20-\% 20$ Micots.pdf

Mobley, H.W. (1970). The Ghanaian's image of the Missionary: An Analysis of Published Critiques of Christian Missionaries by Ghanaians 1897-1965. Leiden: Brill.

Priestley, M. (1969). West African Trade and Coast Society: A Family Study, London: OUP.

Sarbah, J. M. (1968). Fanti National Constitution, London : Cass. Sessarakoo, W. A. (1750). The Royal African: or, Memoirs of the Young Prince of Annamaboe. 2nd ed. London: W. Reeve. [Listed thus on occasions, but written by 'Dodd'. ]

Shumway, R. (2011). The Fante and the Transatlantic Slave Trade.

Rochester: University of Rochester.

Sparks, R. J. (2014). Where the Negroes Are Masters: An African Port in the Era of the Slave Trade, Cambridge: Harvard University Press.

Thomas, R. (1975). 'Military Recruitment in the Gold Coast during the First World War. Cahiers d'études Africaines, 15 (57), 57-83. (Prefers 'Atta' to 'Ata'.) See http://www.persee.fr/web/revues/ home/prescript/article/cea_0008-0055_1975_num_15_57_2610 


\section{On-line sources}

https://www.bigredbook.info/dapper_channon.html Dapper Channon 'This is Your Life', 1958.

http://www.methodistheritage.org.uk/missionary-history-essamuahghanaian-2003.pdf

\section{Appendix: A note on 'native cloth' and 'native names'}

In 1887, John Mensah Sarbah returned to Cape Coast from England, having studied at Queen's, Taunton and qualified at the Inns of Court. Two years later, his nationalism found expression in the establishment of the Mfantsi Amanbuhu Fehu ('Fanti National Society') in Cape Coast. The society's aims included stopping 'further encroachments into (Fanti) nationality' ${ }^{44}$ and its agenda included encouraging pride in the Fanti language and in Fanti culture. Collections were made of proverbs, oral traditions and customary laws, and performances, described under the generic term 'concerts', were organised. Sarbah's conduct at one of these 'concerts' reflects issues in the debate about nationalism. It is described in a report carried by the Gold Coast People, of November 30, and includes:

I failed not to be present at the second concert presided over by Mr J Mensah Sarbah in his native cloth ... Let us be thankful Fantis are proud to be Fantis and not ashamed to be known by their native names, heard speaking their liquid language, and seen arrayed in their flowing robes ... I am sorry I did not wear my cloth on that warm night, I had the misfortune to wear the alien badge of coat and trousers. This is quoted by Harris W Mobley in The Ghanaian's Image of the Missionary: an analysis of the published ... 34 .

We might note that one of Sarbah's contemporaries at Queen's, a Sierra Leonean who was known at school as 'James Davies', 'changed his name' to 'Orishatuke Fadama'. Sarbah's

${ }^{44}$ Sarbah, Fanti National Constitution, 1906, xvii 
countryman, Kobina Sekyi, who may have attended Queen's, contributed to the debate on the wearing of African 'cloth' and to the use of African names. 